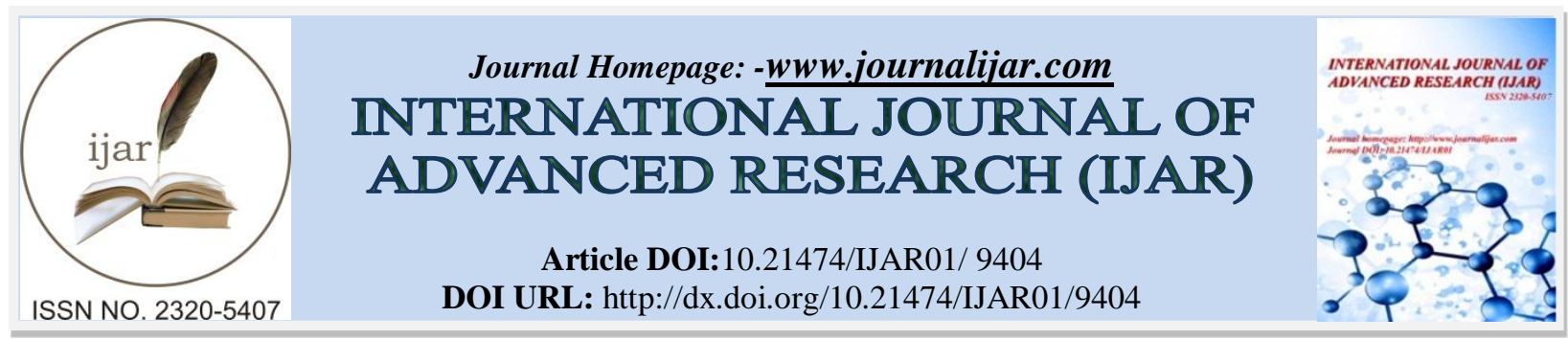

RESEARCH ARTICLE

\title{
MULTIPLE STRATEGIES FOR REDUCING OPEN DEFECATION IN PASURUAN REGENCY, EAST JAVA, INDONESIA.
}

\author{
Wiwik Winarningsih $^{1}$, Z. Fanani ${ }^{2}$, Endah Setyowati ${ }^{2}$ and Jack Rubijoso ${ }^{2}$ \\ 1. Postgraduate student of environmental science, brawijaya university. \\ 2. Postgraduate lecturer of brawijaya university.
}

\section{Manuscript Info}

Manuscript History

Received: 17 May 2019

Final Accepted: 19 June 2019

Published: July 2019

Key words:-

Pasuruan regency, Open defecation, Da'i.

\begin{abstract}
This study was aimed to analyze multiple strategies for reducing open defecation in Pasuruan Regency, East Java, Indonesia. Breakthroughs and innovative policies are needed to accelerate the achievement of stopping open defecation behavior. Based on reports from the Pasuruan Health Office, several factors can cause people to stop practicing open defecation, such as enough amount of toilet and the increasing awareness of health and cleanliness. Da'i is an Islamic religious leader who is close to the community. Da'i educates people about Islam and invites people to do good deed based on Islamic rules. The people in Pasuruan has a robust Islamic boarding school background, so Da'i might have a big role in their way of living.
\end{abstract}

Copy Right, IJAR, 2019,. All rights reserved.

\section{Introduction:-}

Safe drinking water, adequate sanitation, and good hygiene are the basic sanitation need to create a healthy community (WHO, 2018; UNICEF, 2010; Fewtrell et al., 2005). Part of the 2030 agenda of the Sustainable Development Goals is to have $100 \%$ access to clean drinking water, $0 \%$ slum settlement, and $100 \%$ access to effective sanitation (UN, 2018). These targets were also adopted by the Indonesian government through the Indonesian national development plan or Rencana Pembangunan Jangka Menengah Nasional (RPJMN) 2015-2019 (BAPPENAS, 2018). To achieve these targets, the Indonesian government have run many programs, and one of the agenda is to decrease the number of open defecation practice in Indonesia.

The behavior of open defecation is one example of unhealthy behavior (Spears, et al. 2013; O'connell, 2014). An open defecation is an act of excretion in the fields, forests, bushes, rivers, beaches, or other public areas. Open defecation behavior can cause contamination in the environment, soil, air, and water (Caimcross et al., 1998). Contamination to water can lead to other problems because it reduces the amount of available clean drinking water (WHO, 2011). High levels of open defecation are also linked to many health problems, such as diarrhea (Jung et al., 2017) and intestinal worm infections (Unger and Riley, 2007; Boschi-Pinto et al., 2009). Open defecation can also indirectly cause high child mortality (Victoria, 2008; Wang et al., 2015).

Based on WHO data (2010), it is estimated that 1.1 billion people or $17 \%$ of the world's population still defecate in open areas. $82 \%$ of this 1.1 billion people lives in 10 countries : India (58\%), Indonesia (5\%), China (4.5\%), Ethiopia ( 4.4\%), Pakistan (4.3\%), Nigeria (3\%), Sudan (1.5\%), Nepal (1.3\%), Brazil (1.2\%) and Niger (1.1\%). Based on this data, Indonesia shown as the second largest country practicing open defecation. In Indonesia, $5 \%$ of 
the population still defecating in open areas reflects $26 \%$ of the total population of Indonesia (UNICEF Indonesia, 2010). Similar to WHO data, research by Ministry of health in 2010 showed that $36.4 \%$ of the total population in Indonesia still defecating in open areas, and only $55.5 \%$ of the total population have access to the basic sanitation facility.

One of the city in Indonesia with a high level of Open defecation is Pasuruan Regency, East Java (Ministry of health, 2007; Ministry of health, 2010). The sanitation and access to clean water and drinking water conditions in Pasuruan Regency were still relatively poor and far from the SDGs target. The Pasuruan regency government has implemented a sanitation program (Community Based Total Sanitation, Kemkes, 2009) to decrease the rate of open defecation since 2013. However, the achievements have not yet significant. The non-significant achievements can be seen from the data of people who still practice open defecation. At the year 2013, 2014, and 2015, approximately 175979, 176719, and 170625 families still defecate in open areas (Pasuruan regency, unpublished data). If this trend continues, then the target of completely stop open defecation in Pasuruan Regency will only be reached in 2043 or the next 25 years.

Breakthroughs and innovative policies are needed to accelerate the achievement of stopping open defecation behavior. Based on reports from the Pasuruan Health Office, several factors can cause people to stop practicing open defecation, such as enough amount of toilet and the increasing awareness of health and cleanliness (Mara, 2017; Dahal, 2014; Srinivasan and Geetha, 2014). Pasuruan regency government have built an enormous amount of permanent healthy public toilets since 2013, but still, need improvement on programs related to increasing public awareness on the danger of open defecation. So far, the program to increase public awareness on the danger of open defecation is carried out conventionally by the health office through health workers and sanitarians in each subdistrict. For an innovative attempt, Pasuruan government have involved Da'i to help increase public awareness on the danger of open defecation.

Da'i is an Islamic religious leader who is close to the community. Da'i educates people about Islam and invites people to do good deed based on Islamic rules (Mubasyaroh, 2016). The people in Pasuruan has a robust Islamic boarding school background, so Da'i might have a big role in their way of living (Mukhlis, 2009). Da'i has the potential to help to decrease open defecation by inviting people to have a healthy living behavior (Risdiana, 2014). The potential is supported by the concept of Islamic teaching. Islam is a religion that emphasizes cleanliness and environmental health (Yusuf, 2015). Guidances about health is clearly written in the Qur'an and the Hadith of the Prophet. In this study, we evaluate the factors that can reduce open defecation practice in Pasuruan, such as water quality, the availability of sanitation facility, and the effectiveness of Da'i sanitation's role in increasing public awareness to not defecate in open areas.

\section{Research Purpose:-}

Based on the formulation of the problem above, the objectives of this study are as follows:

Analyze multiple strategies for reducing open defecation in Pasuruan Regency, East Java, Indonesia.

\section{Research Methods:-}

Study sites and Data sampling:-

The study was conducted in 24 districts inside Pasuruan regency (Figure 1) from 2016 to 2018. We used the survey method to take samples from a population using questionnaires as a tool. We used Stratified Random Sampling that allows us to select the sample/respondent to get the information that we want. The respondents were families that are still practicing open defecation. There were 1200 respondents in total, 50 respondents in each district. We interviewed the respondent with questionnaires. We also documented the facility related to sanitation in each area to get information on the number of available public toilets. We refer to Winarningsih (2019) for water quality data on each district.

There are two types of data that were collected in this study, primary and secondary data. Primary data is needed for testing predetermined hypotheses, while secondary data is needed to provide a description (description) of the object of research. Primary data includes the respondent's individual information, their reason to still defecate in the open area, their ability to access public toilets or other facility related to sanitation, and their perception of Da'i. The secondary data are taken from agencies associated with this research, such as health agencies and the district government. 


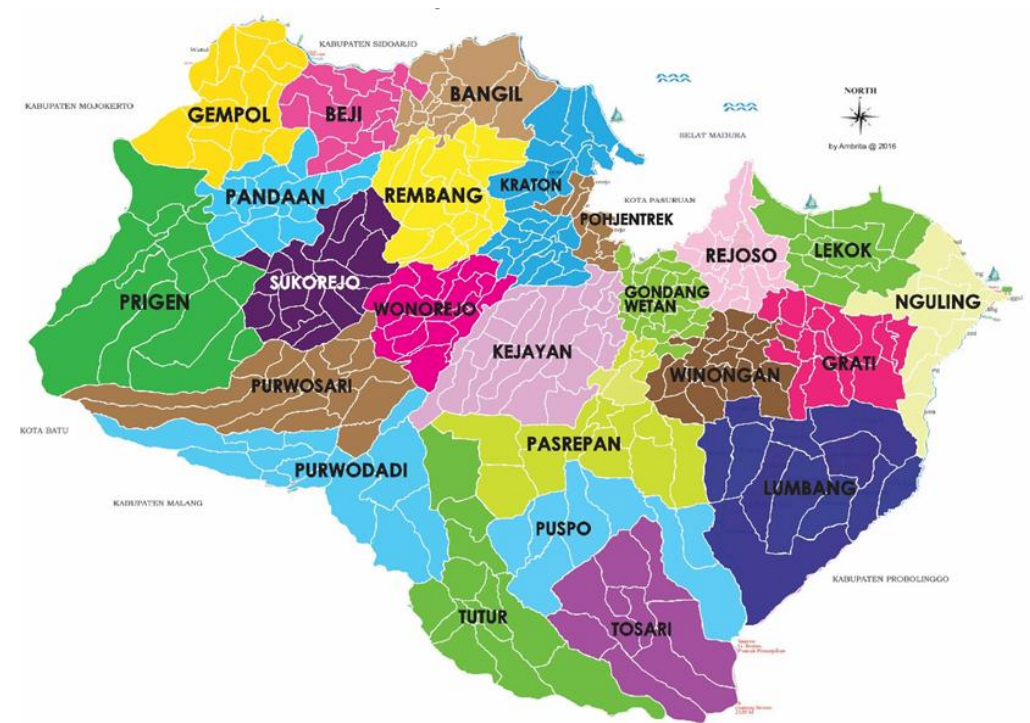

Figure 1:-The study sites, 24 districts in Pasuruan Regency

\section{Data analysis:-}

We evaluate the fluctuation of open defecation cases in 2016-2018 and relate that with the number of available sanitation facility (permanent healthy toilets) by making graphics on Microsoft Excel 2007 for Windows. We also link those data with water quality data taken from Winarningsih (2019). Furthermore, to have a better idea of Da'i role to increase public awareness on the danger of open defecation, we analyzed the data using Structural Equation Modelling (SEM) method (Ghozali and Fuad, 2005). Structural Equation Modelling (SEM) method is commonly used to tests the validity and reliability of data, and also to reveal the pattern of relationships between one or several independent variables on one or several dependent variables (Hair et al., 2006). There are five variables included in the model: Da'i, JSP (Permanent Healthy toilet or Jamban Sehat Permanen), K-AIR (water quality), DIARE (diarrhea), and BABS (Open defecation cases). We used SEM calculation tool in WarpPLS 3.0 program.

\section{Research Result And Discussion:-}

Open defecation cases in each district in Pasuruan from 2016 to 2018:-

There are differences in the trends of open defecation practices in each district of Pasuruan Regency. The number of open defecation cases decreasing significantly in all district in the year 2017 compared to the previous year (Figure 2). Lekok district makes an outstanding improvement in reducing the open defecation cases in 2017. However, the decreasing trends in all districts did not continue to the next year, 2018. Compared to 2017, the number of open defecation cases in 2018 decreased in 22 districts, although not significant. However, the number of open defecation cases stagnant in one district (Rembang) and unfortunately increased in one district (Purwodadi). One thing for sure is that the overall trends showed a decreasing number of open defecation cases for the last three years. 


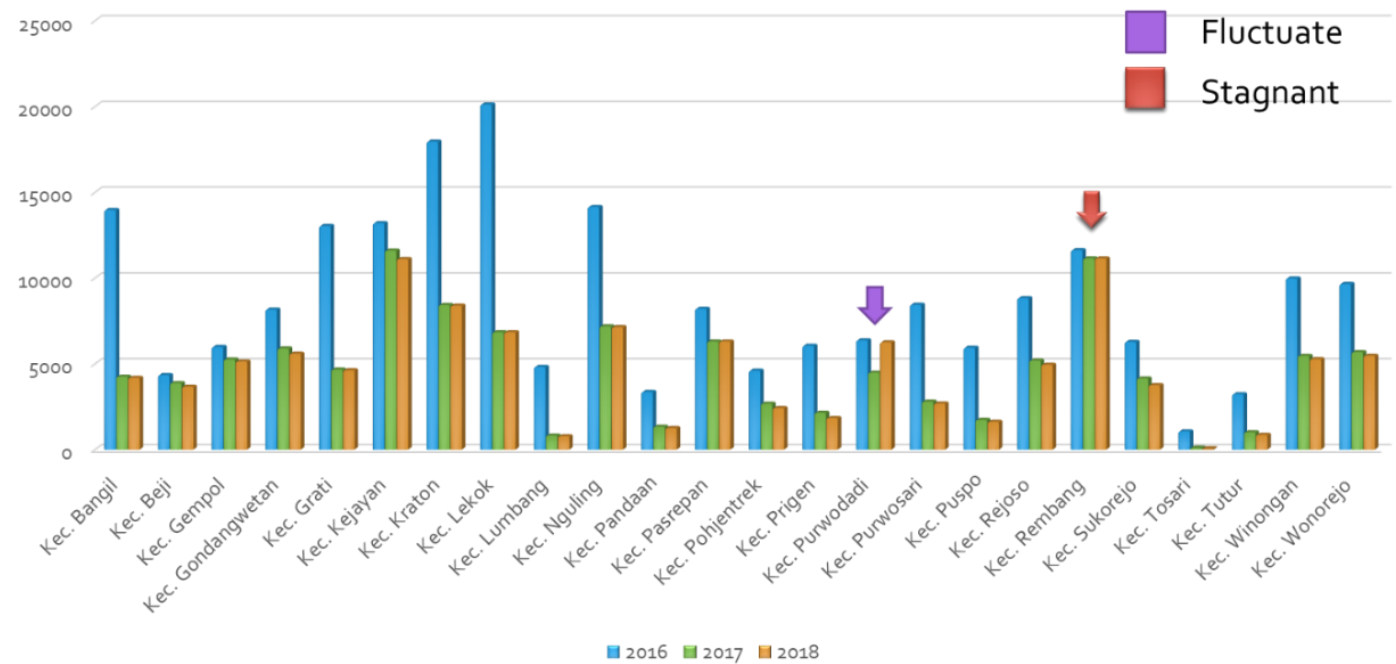

Figure 2:-The number of open defecation cases in each district from 2016 to 2018. Majority of the district showed a decreasing trend.

The number of permanent healthy toilets observed in each district in Pasuruan from 2016 to 2018:-

The general trend of the number of toilets is increasing from 2016 to 2018 (Figure 3). In most of the district, the number of permanent healthy toilets increase significantly in 2017. Even not as significant as in 2017, the increasing trend continues to the next year, 2018. If we compare the progress of permanent healthy toilet builds in each district, 18 from 24 districts have increased the number of toilets significantly in each year. However, the number of public toilets decreased each year in 3 out of 24 districts (Lumbang, Prigen, Tutur). In 2 districts, Kejayan and Purwodadi, the number of toilets increased in 2017 but decreased in 2018 compared to 2016. Lastly, the number of toilets do not increase nor decrease at all years for one district, Rembang.

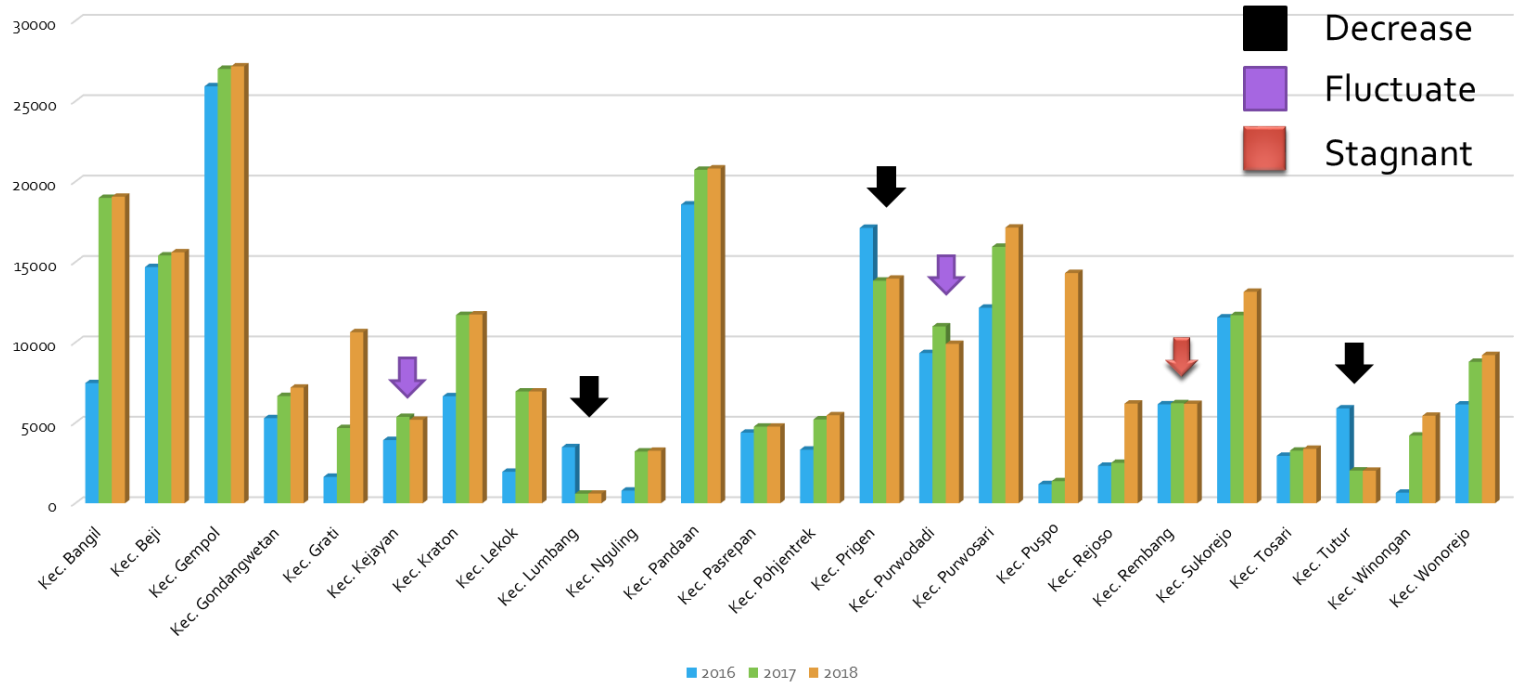

Figure 3:-The number of permanent healthy toilets in each district from 2016 to 2018. Although the number oftoilets increased in most of the districts, fluctuation and stagnancy were also observed in some districts

The role of Da'i to decrease open defecation cases:-

We generate models to understand the role of Da'i to help increase awareness of the danger of open defecation. We assessed the relationship between five variables: Da'I, JSP (Healthy toilet or Jamban Sehat Permanen), K-AIR (water quality), DIARE (diarrhea), and BABS (Open defecation). The result of the analysis shows that there was a direct and indirect influence on the structural model that was built. 


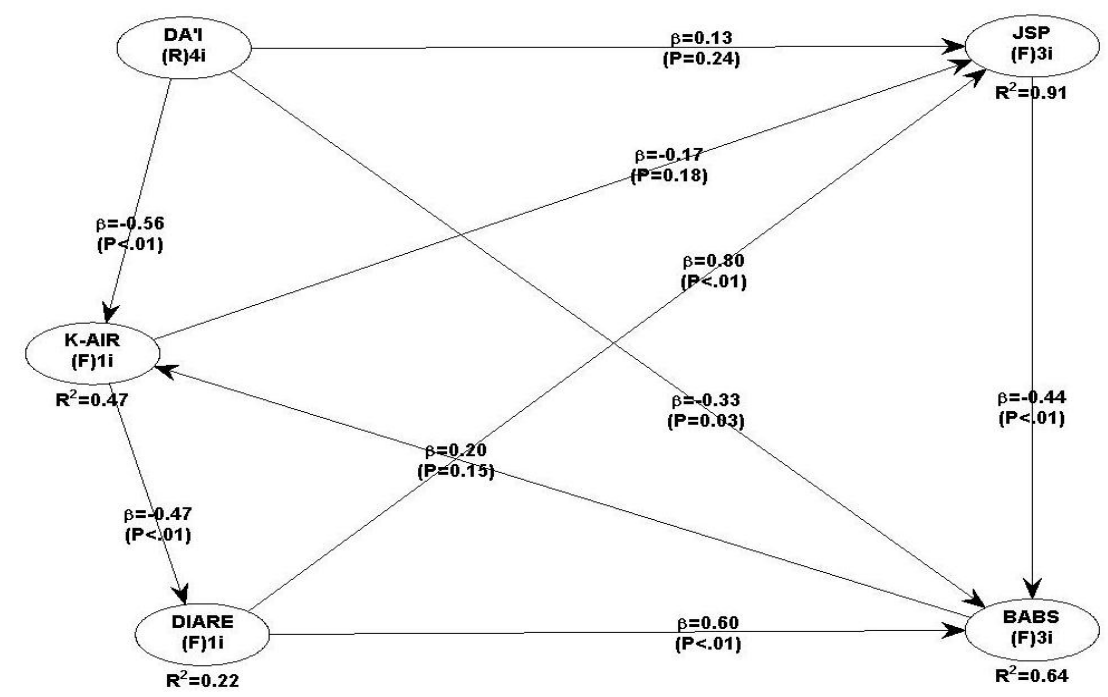

Figure 4:-Best models showing the relationship between Da'i, water quality, diarrhea cases, the number of permanent healthy toilets, and open defecation in Pasuruan Regency

The best model (Average R-squared (ARS) $=0.559, \mathrm{P}<0.001$ ) showed a significant direct impact between the role of $\mathrm{Da}^{\prime} \mathrm{i}$ on water quality (path coefficients $-0.56, \mathrm{p}<0.001$ ). Although not significant, Da'i also has a positive impact on the permanent healthy toilet (JSP) with path coefficient 0.13 , which mean that Da'i could have influenced people to build a healthy toilet. Water quality has a significant negative direct impact on diarrhea (path coefficients $-0.47, \mathrm{p}$ $<0.001)$, which mean that better water quality will reduce diarrhea cases. In the Diarrhea variable, there is a significant direct effect ( $<<0.001, \alpha 1 \%$ ) on the permanent healthy toilet (JSP) and open defecation cases (BABS) with path coefficient values 0.80 and 0.60 , respectively. Presumably, diarrhea cases could influence people to have a better life with building permanent healthy toilet (JSP), and high level of diarrhea was related to a high level of open defecation. Lastly, permanent healthy toilet (JSP) has a very significant direct effect ( $p<0.01, \alpha 1 \%$ ) with the path coefficient -0.44 for the open defecation cases (BABS) variable, meaning that an increasing number of the permanent healthy toilet (JSP) will reduce open defecation cases (BABS).

\section{Discussion:-}

The "Stop Open Defecation" programs involving Da'i in Pasuruan district showed a sign of good achievements. The number of open defecation cases in Pasuruan district generally decreased from 2016 to 2018. Similar to this improvement, the number of permanent healthy toilet (JSP) increased in 18 out of 24 districts from the year 2016 to 2018. We also found that Da'i can help improve the number of permanent healthy toilet (JSP) and indirectly help decrease the open defecation (BABS) cases. These result showed that by increasing public awareness of healthy living, they would be moved to build a permanent healthy toilet (JSP) and eventually stop the habit of defecating in open areas.

In some of the districts, for example, Lumbang, Prigen, and Tutur, the number of open defecation cases decreased even when the number of permanent healthy toilet also decreased. So the people in these districts do not depend on the presence of permanent healthy toilet (JSP) to stop the habit of defecating in open areas. This phenomenon showed that there is a good public awareness of healthy living. This kind of case showed the result of successful education by health workers and Da'i.

Da'i plays a great role in solving problems that exist in Islamic society (Vyas and Spears, 2018), especially in Java, Indonesia (Lukens-bull, 2000). In our study, Da'i can have a great influence on the people in Pasuruan regency maybe because of two correlated factors. The first factor is the Pasuruan community culture that is dominated by Islamic cultures and values. In Islamic culture, Da'i has a fundamental role. Da'i is the leader, influencer, teacher, and also the doctor in the Islamic community (Ratoni, 2015). Therefore, Pasuruan residence will have great trust in Da'i. 
The second reason is the low level of education. Duverger (2010) states that a person's education level determines their perspective on health aspects. The Pasuruan district residences that still defecate in open area mostly had a low education level. Therefore, it is hard for this community to understand the risk of open defecation even though health workers already informed them. Notoadmojo (2007) states that a low level of education will cause the information conveyed by the speaker to be very difficult to digest and understood. Meanwhile, Da'i has a robust place in this kind of community. Even though the uneducated community could not understand the information to stop open defecation, if the provision of information is conveyed by people who they obey, then the information from Da'i will be accepted by the community (Darmawan et al., 2013).

In Islamic countries, especially in southeast Asia where the people are not evenly educated and poor, religion is the primary tool that could shape the community health condition (Levin, 1996; Vyas and Spears, 2018). A health study in the Middle East and North Africa (MENA) countries by Goldstein, 2016 found that by utilizing Islamic texts such as the Quran and Sunnah, and also by employing religious leaders as spokespersons, the communities in MENA countries respond positively to the health promotion, and many health programs result in positive outcomes. Generally, religious practices and beliefs must be taken into account to develop a health system in religiousdeveloping countries, for example, the MENA countries, and probably also Indonesia.

Even though Da'i and health workers of Pasuruan Regency have successfully decrease open defecation in some district, the number of open defecation cases fluctuated according to the number of the permanent healthy toilet in Purwodadi district. Presumably, the people of Purwodadi district only willing to stop defecating in open areas when there is a healthy toilet available, showing that their awareness of healthy living is not as good as people from former districts (Lumbang, Prigen, and Tutur).

The decrease in the number of permanent healthy toilet was due to the abandonment of those toilets. In some districts, the healthy toilets were too far, so not many people come to those toilets, and eventually, those toilets were abandoned and damaged. Or in another case, the toilets were damaged naturally but the residence of that particular area unable to repair it due to several reasons such as finance and time, so they abandoned those damaged toilets. In this kind of cases, the health workers and government workers need to support financially and educate the residents on how to manage the permanent healthy toilets.

For Rembang district, the number of open defecation cases did not change from 2016 to 2018. The number of available permanent healthy toilet also remain stagnant for all three years. The Da'i and health workers in this district work as hard as in another district, so there must be another reason why the stop open defecation program did not work in this district.

Besides the existence of permanent healthy toilets and the role of health workers or Da'i, several other factors can influence the success of stopping open defecation behavior. These factors include community characteristics, economic level, education, and regional topography (Widayanti, 2012). After spending time for further study, we found out that this district has limited access to clean water. Water quality study by Winarningsih (2019) showed that there are only three water stations available in Rembang district, and the water does not pass the drinking water standard according to the biological parameters. Therefore, this district needs special care to provide clean water, and management strategies to prioritize the available clean water for drinking and health care in this region (Whittington et al., 2012).

There is a need to evaluate the Da'i Sanitation Program in the near future. The result of this study showed a significant decrease in open defecation rate in 2017, but not significant in 2018 (Figure 2). The stop open defecation program in Pasuruan regency was first started in 2013, and after intense training, in 2016 the Da'i began to be involved in community sanitation education activities. The spirit of the Da'i is high only in the first year, but the Pasuruan regency did not develop any monitoring programs to keep the spirit high in the following years. In the future, Pasuruan Regency needs to develop a program to keep the Da'i spirit high.

Pasuruan Regency targeted to completely stop open defecation in accordance with the national program (Community-Based Total Sanitation) 2013. Based on the result of this study, there is a potential of one district to be an Open Defecation Free district. Tosari district has the least number of open defecation cases in 2018. This district showed an improvement on the decreasing number of open defecation cases and the increasing number of permanent healthy toilets. The water quality in all water station in this district was way above the drinking water 
standard according to the biological parameters. The people of this district were aware of healthy living behavior, so their behavior connected and adapted to shape their healthy environment (Antonovsky, 1979). Pasuruan Regency should monitor the health program in this district closely, and implement the positive things to the programs in other districts.

\section{Cnclu}

The main factor that is influencing people behavior to stop defecating carelessly in Pasuruan Regency is the availability of permanent healthy toilets and the role of Da'i. The existence of Da'i in Pasuruan Regency to spread awareness of the danger of open defecation shows a positive influence. The number of open defecation cases generally decreased from 2016 to 2018, and the number of permanent healthy toilets increased. The Pasuruan regency communities that dominated with Islamic cultures believe that they can get blessings thinks if they can implement all recommendations or solicitation conveyed by Da'i. Although there are other factors (economic level, management, and regional topography) that detain the stop open defecation program in Pasuruan, an educational activity involving Da'i should be continued until Pasuruan regency become an 'open defecation free' regency.

\section{Conclusion:-}

Drinking water stations in districts of Pasuruan are still remain in poor quality. The coliformic bacteria contamination especially $E$. coli in drinking water stations is the main problem that cause the quality becomes poor and can not fulfil the drinking water standard according to the biological parameters. Therefore, strategy to reduce the coliformic bacteria including E. coli contamination on drinking water stations is needed to develop for further increase the drinking water quality in Pasuruan Regency of East Java, Indonesia.

\section{Acknowledgement:-}

We were thanks to Health Department of Pasuruan Regency government. We thanks also to research volunteer from District's Public Health Center for collecting data. In deep thanks also for Head of Districts and Villages for accomodating field trips inspecting the villages environment.

\section{Bibliography:-}

1. Antonovsky, A. 1979. Health, Coping, and Stress. 1st Ed California: JosseyBass Inc, California.

2. BAPPENAS. 2018. RPJMN. https://www.bappenas.go.id/id/data-dan-informasi-utama/dokumen-perencanaan-danpelaksanaan/dokumen-rencana-pembangunan-nasional/rpjp-2005-2025/rpjmn-2015-2019/. Accessed on 26 November 2018 11.15 WIB.

3. Boschi-Pinto C, Lanata CF, Black RE. 2009. The global burden of childhood diarrhea. In: Ehiri JE, editor. Maternal and Child Health. Springer Science and Business Media. 3: 225-243.

4. Cairncross S, Blumenthal U, Kolsky P, Moraes L, Tayeh A. 1996. The public and domestic domains in the transmission of disease. Trop Med Int Heal. 1(1):27-34. Available from: http:// www.ncbi.nlm.nih.gov/pubmed/8673819

5. Dahal, K. R., Bikash A., and Jyoti T. 2014. Sanitation Coverage and Impact of Open Defecation Free (ODF) Zone with Special Reference to Nepal: A Review. Int. Journal of Engineering Research and Application. 4 (8): $118-128$.

6. Darmawan, E.D., P. Junadi, A. Bachtiar, and M. Najib, 2013. Mengukur Tingkat Pemberdayaan Masyarakat dalam Sektor Kesehatan. Kesmas, Jurnal Kesehatan Masyarakat Nasional. 7 (2): 1-7.

7. Duverger, M. 2010. Sosiologi Politik. Rajagrafindo Persada. Jakarta.

8. Fewtrell, L., Kaufmann, R.B., Kay, D., Enanoria, W., Haller, L. and Colford Jr, J.M. 2005. Water, sanitation, and hygiene interventions to reduce diarrhea in less developed countries: A systematic review and meta-analysis. Lancet infect dis. 5: 42-52.

9. Ghozali, I dan Fuad. 2005. Structural Equation Modeling: Teori, Konsep, dan Aplikasi. Badan Penerbit Universitas Diponegoro. Semarang.

10. Goldstein, Perri. 2016. Religion as a Social Determinant of Health in Muslim Countries: The Implementation of Positive Health Promotion. Independent Study Project (ISP) Collection. 2354. https://digitalcollections.sit.edu/isp_collection/2354

11. Hair, J.F. JR., Anderson, R.E, Tatham, R.L. \& Black, W.C. 2006. Multivariate Data Analysis. Six Edition. Pearson Educational, Inc. New Jersey.

12. Jung YT, Hum RJ, Lou W, Cheng Y-L. 2017. Effects of neighborhood and household sanitation conditions on diarrhea morbidity: Systematic review and meta-analysis. PLoS ONE 12(3): e0173808.https://doi.org/10.1371/journal. pone.0173808

13. Kemkes. 2009. STBM Provinsi Jawa Timur: "Dakwah Sanitasi, Sanitasi Total Berbasis Masyarakat." http://stbm.kemkes.go.id/ Accessed on 26 November 2018 11.50 WIB. 
14. Levin, Jeffrey S. 1996. How Religion Influences Morbidity and Health: Reflections on Natural History, Salutogenesis, and Host Resistance. Social Science \& Medicine, XIVth International Conference on the Social Sciences and Medicine. 43 (5): 849-864. doi:10.1016/0277-9536(96)00150-5

15. Lukens-Bull, Ronald A. 2000. Teaching morality: Javanese Islamic Education in A Globalizing Era. Journal of Arabic and Islamic Studies. 3:26-47.

16. Mara, Duncan. 2017. The elimination of open defecation and its adverse health effects: a moral imperative for governments and development professionals. Journal of Water, Sanitation and Hygiene for Development. 7 (1): 1-12.

17. Ministry of Health. 2008. Laporan Nasional: Riset Kesehatan Dasar (Riskesdas) 2007, Jakarta: Ministry of Health, National Institute of Health Research and Development.

18. Ministry of Health. 2011. Laporan Nasional: Riset Kesehatan Dasar (Riskesdas) 2010, Jakarta: Ministry of Health, National Institute of Health Research and Development

19. Mubasyaroh, 2016. Manajemen Sumber Daya Manusia (Msdm) Da'i Melalui Pelatihan Dalam Pengembangan Dakwah Islam. Tadbir Vol. 1, No. 1.

20. Mukhlis, A. 2009. Pengembangan Masyarakat Islam Dalam Sistem Dakwah Islamiyah. Jurnal Ilmu Dakwah Vol. 4 No. 14.

21. Notoatmojo, S. 2012. Promosi Kesehatan dan Perilaku Kesehatan. PT. Rineka Cipta. Jakarta.

22. O'Connell, K. 2014. Findings from a global review, Scaling up rural sanitation. DC, USA: World Bank; Water and Sanitation Program, Washington.

23. Ratoni, Muhammad. 2015. Integrasi Konsep Islam dalam Konteks Promosi Kesehata. Al-mabsut : Jurnal Studi Islam dan Sosial. 9(2) : 41-58

24. Risdiana, A. 2014. Transformasi Peran Da'i dalam Menjawab Peluang dan Tantangan (Studi Manajemen SDM). Jurmal Dakwah. 15: 433-451.

25. Spears, D., Ghosh, A., \& Cumming, O. 2013. Open defecation and childhood stunting in India: An ecological analysis of new data from 112 districts. PloS ONE 8(9): 1-10.

26. Srinivasan S.K and Geetha J. 2014. Open Defecation: Awareness \& Practices of Rural Districts of Tamil Nadu, India. International Journal of Scientific Research 3 (5): 537-539.

27. UN. 2018. Sustainable development goals. https://www.un.org/sustainabledevelopment/sustainable-developmentgoals/. Accessed on 26 November 2018 12.20 WIB.

28. Unger, A. and Riley, L.W. (2007) Slum health: From understanding to action. PLoS Med 4(10): e295. doi:10.1371/journal.pmed.0040295.

29. UNICEF INDONESIA. 2010. Air Bersih, Sanitasi, dan Kebersihan. p.1-6.

30. UNICEF. 2010. Progress on Sanitation and Drinking-Water. p. 22 - 52

31. Victoria, C.G., Adair, L., Fall, C., Hallal, P.C., Martorell, R., Richter, L. and Sachdev, H.S. (2008): 'Maternal and child undernutrition: consequences for adult health and human capital.' Maternal and Child Undernutrition 2, Lancet 371: 3403-3457

32. Vyas, S and Spears D. 2018. Sanitation and Religion in South Asia: What Accounts for Differences across Countries? The Journal of Development Studies. 54(11): 2119-2135

33. Wang H, Naghavi M, Allen C, Barber RM, Bhutta ZA, Carter A, et al. Global, regional, and national life expectancy, all-cause mortality, and cause-specific mortality for 249 causes of death, 1980-2015: a systematic analysis for the Global Burden of Disease Study 2015. Lancet. 388(10053):1459-544.

34. Whittington, D., Marc J., Kate B., Yvonne Y. 2012. Setting Priorities, Targeting Subsidies among Water, Sanitation, and preventive Health Interventions in Developing Countries. World Development 40 (8) 1546-1568.

35. WHO. 2011. Guidelines for drinking-water quality - 4th ed. http://www.who.int/ Accessed on 26 November 2018 16.30 WIB.

36. WHO. 2018. Sanitation. http://www.who.int/topics/sanitation/en/. Accessed on 26 November 201810.17 WIB.

37. Widayanti, S. 2012. Pemberdayaan Masyarakat: Pendekatan Teoritis. Jurnal Ilmu Kesejahteraan Sosial. 1(1) : 87102.

38. Winarningsih, W., Endah S., Jack R., and Zaenal F. 2019. Reducing Escherichia coli Contamination on Drinking Water Stations in Pasuruan, East Java, Indonesia. Paper on the process of publishing.

39. Yusuf, M. 2015. Da‘i Dan Perubahan Sosial Masyarakat. Jurnal Al-Ijtimaiyyah. Vol. 1 (1). 